\title{
A review on bioremediation of pulp and paper mill effluent - An alternative to conventional remedial technologies
}

\author{
Sangeeta Madan $^{1 *}$, Preeti Sachan ${ }^{1}$ and Utkarsh Singh ${ }^{2}$ \\ ${ }^{1}$ Department of Environmental Sciences, Kanya Gurukul Campus, Gurukul Kangri University, Haridwar-249404 \\ (Uttarakhand), INDIA \\ ${ }^{2}$ Department of Biotechnology, Baba Farid Institute of Technology, Dehradun-248001 (Uttarakhand), INDIA \\ *Corresponding author. E -mail: n.madan79@yahoo.com
}

Received: August 17, 2017; Revised received: November 24, 2017; Accepted: February 10, 2018

\begin{abstract}
At present, a large amount of water required for paper production and various chemicals has been identified in effluents, which is produced at different steps of paper making in paper mills. The pulp and paper industry is typically related to pollution difficulties related to high biological oxygen demand (BOD), chemical oxygen demand (COD), colour, suspended solids, lignin and chlorinated compounds. Several studies have been made on eliminate these difficulties of pulp and paper effluents, the problem still continues. Although the physical and chemical methods are on the track of treatment, they are not on par with biological treatment because of cost ineffectiveness and residual effects. The biological treatment is known to be effective in reducing the organic load and toxic effects of paper mill effluents. Some microorganisms including bacteria and fungi have been involved in degrading the chemicals present in pulp and paper mill effluent. This article is an overview of the attempts made by several researchers worldwide to use biotechnological methods for degradation of the toxic compounds present in pulp and paper mill effluents by using fungi, bacteria, algae and enzymes. The current study clearly shows that application of native dominant bacterial and fungal isolates may be used forthe treatment of large pulp and paper mills effluents.
\end{abstract}

Keywords: Algae, Bacteria, Effluent, Enzymes, Fungi, Pulp and paper mill

\section{INTRODUCTION}

Development increases the financial value of a nation, but concurrently it leads to the degradation of the environment (Hossain and Rao, 2014). Financial profit of the pulp and paper industry has controlled it to be one of the most important industrial sections in the world. Still, now, pulp and paper mills are facing challenges with the management of the resulting pollutants (Kamali and Khodaparast, 2015).The pulp and paper industry has been considered to be a major consumer of natural resources and significant contributor of pollution to the environment. The pulp and paper industry is the sixth largest polluter globally, discharging a variety of gaseous, liquid and solid wastes into the environment (Monte et al., 2009).

These pulp and paper industries generate 220$380 \mathrm{~m}^{3}$ of highly coloured and potentially toxic wastewater for every tonne of paper produced (Badar and Farooqui, 2011).That effluent needs appropriate treatment prior to release in the environment; otherwise, it represents a major environmental problem. The main problem is the persistent dark brown colour due to lignin and its derivatives (Prasongsuk et al., 2009). The effluent cause huge damage to the receiving water if discharged untreated because it has high biological oxygen demand (385 mg/l), chemical oxygen demand $(792 \mathrm{mg} / \mathrm{l})$, total dissolved solids $(850 \mathrm{mg} / \mathrm{l})$, lignin (436 mg/l), phenol (42 mg/l), sulphur and sulphur compounds (993 mg/l) (Raj et al., 2014).

The increasing strict regulations established by many authorities and agencies are forcing the industry to treat effluents to the required permissible level before releasing in to the environment (D'Souza et al., 2006). Various studies have been conducted regarding the environmental impacts and the control of the pollutants. But very few reports are present for the comparative assessment of various biological treatment processes (Hanafy et al., 2007).

The term biodegradation has been used to describe the conversion of every type including those that yield products more complex than the starting material as well as those responsible for the complete oxidation of compounds to $\mathrm{CO}_{2}, \mathrm{H}_{2} \mathrm{O}, \mathrm{NO}_{3}$ and other inorganic compounds (Atlas and Bartha, 2003). Bioremediation is defined as the process in which organic wastes are biologically degraded under controlled conditions to an innocuous state, or to levels below concentration limits established by regulatory authorities (Mueller et al., 1996). The term mineralization is the ultimate degradation and recycling of organic molecule to its mineral 
Table 1. Physicochemical characteristics of pulp and paper mill effluent (Raj et al., 2014).

\begin{tabular}{lll}
\hline S.N. & Parameters & Calculated values \\
\hline 1 & pH & $8.2 \pm 1.0$ \\
2 & TDS & $850 \pm 30 \mathrm{mg} / 1$ \\
3 & COD & $792 \pm 70 \mathrm{mg} / 1$ \\
4 & BOD & $385 \pm 12 \mathrm{mg} / 1$ \\
5 & Colour (CU) & $2242 \pm 56$ \\
6 & Lignin & $436 \pm 18 \mathrm{mg} / 1$ \\
7 & Total nitrogen & $116 \pm 32 \mathrm{mg} / 1$ \\
8 & Sulphate & $993 \pm 6 \mathrm{mg} / \mathrm{l}$ \\
9 & Phosphate & $8.3 \pm 0.3 \mathrm{mg} / 1$ \\
10 & Nitrate & $73.3 \pm 6 \mathrm{mg} / 1$ \\
11 & Total phenol & $42 \pm 2.5 \mathrm{mg} / 1$ \\
12 & Heavy metals & \\
& Cu & $0.09 \pm 0.1 \mathrm{mg} / 1$ \\
& Fe & $10.22 \pm 9 \mathrm{mg} / 1$ \\
& Ni & $5.03 \pm 1 \mathrm{mg} / \mathrm{l}$ \\
& $\mathrm{Zn}$ & $9.83 \pm 1 \mathrm{mg} / \mathrm{l}$ \\
& $\mathrm{Mn}$ & $0.04 \pm 0 \mathrm{mg} / \mathrm{l}$ \\
\hline
\end{tabular}

constituents. The fundamental process of the bioremediation is the natural process of biodegradation, in which the concentration of pollutants can reduce and sometimes can completely oxidize the compound.

The biological colour removal process is particularly attractive since in addition to colour and COD it also reduces BOD and low molecular weight chlorolignins (Nagarthnamma et al., 1999). Microorganisms speedily degrade few chemicals and eliminate them from the environment, but some chemicals are degraded slowly, accumulate in the environment and occasionally exhibit toxicity (Alexander, 1981). Biodegradation of dangerous substances in the environment represents significant prospective methods when complex and ecologically unstable pollutants are converted into simpler substances (stable ones) by the action of microorganisms. The principle of biodegradation technologies is based on optimization of nutrient ratios to support the growth of selected microorganisms able to degrade the target contaminants and application of selected isolated microorganisms with relevant degradation abilities (Kucerova, 2006). Treatment of pulp and paper mill effluent (PPME) has not proved successful due to lack of the desired microorganism, loss of genetic potentiality in adverse environmental conditions, the formation of recalcitrant compounds and poor process optimization for treatment at large scale. Although the physical and chemical methods are applied for treatment they are not better than biological treatment because of cost ineffectiveness and residual effects. The various enzymes implicated in the treatment of PPME are lignin peroxidase, manganese peroxidase and laccase (Malaviya and Rathore, 2007). Microorganisms showing good production of these enzymes have the strength to treat the effluent.

This article is a summary of the attempts made by several researchers worldwide to use biotechnological methods for degradation of the toxic compounds present in pulp and paper mill effluents by using fungi, bacteria, algae and enzymes.

Properties of pulp and paper mill effluent: The paper production process involves several steps and each step can be carried out by various methods. As a result, the final effluent is a mixture of waste water from each process. Table 1 summarizes the main pollutants, which are normally produced during pulp and paper making process (Raj et al., 2014). In debarking process, the plant fibers are converted into smaller pieces called chips that remove the bark. In pulping process, the chips converted into pulp. After pulping, bleaching process is applied to the brown pulp to obtain the desired colour. In the washing process, the bleaching agents are removed from the pulp. Finally, the paper produced by mixing the washed pulp with appropriate fillers and sizing agents like resin and starch. The pollutants at various stages of the pulping and paper making process are presented in Table- 2 .

The pulp and paper industry produces effluents having large BODs and CODs. One of the specific problems that yet not been solved is the strong black brown color of the effluent, which is due to lignin and its derivatives, mainly from pulping, bleaching and chemical recovery stages. Due to brown color of the effluent water temperature increases and photosynthesis decreases, both effects may lead to decreased concentra-

Table 2. Pollutants from various sources of pulp and paper mill (US EPA, 1995).

\begin{tabular}{ll}
\hline Debarking process & The soils, dirts, and barks are removed from the wood and chips are separated from the barks and water \\
is used to clean the wood. Thus the wastewater from this source contains suspended solids, BOD, dirt, \\
grit, fibers etc.
\end{tabular}


Table 3. Microorganisms used for biodegradation of PPME.

\begin{tabular}{|c|c|}
\hline Microorganisms & Authors \\
\hline \multicolumn{2}{|l|}{ Fungi } \\
\hline Trametes versicolor & $\begin{array}{l}\text { Dashtbanet al. (2010), Senthilkumaret al. (2014), Demir et al. (2007) and Kamali and } \\
\text { Khodaparast (2015) }\end{array}$ \\
\hline Phaenerochaete chrysosporium & Tikuet al. (2010), Senthilkumaret al. (2014) and Kamali and Khodaparast (2015) \\
\hline Tinctoporia borbonica & $\begin{array}{l}\text { Senthilkumaret al. (2014), Demir et al. (2007), Verma and Madamwar (2002), } \\
\text { Gomaa et al. (2008) and Kamali and Khodaparast (2015) }\end{array}$ \\
\hline Schizophyllum commune & $\begin{array}{l}\text { Senthilkumaret al. (2014), Demir et al. (2007), Verma and Madamwar (2002) and Gomaa et } \\
\text { al.(2008) }\end{array}$ \\
\hline Aspergillus niger & Sarithaet al. (2010), Senthilkumaret al. (2014) and Kamali and Khodaparast (2015) \\
\hline Gloephyllum trabeum & Patel and Madamwar (2002) and Gomaa et al. (2008) \\
\hline Trichoderma spp. & Senthilkumaret al. (2014) and Kamali and Khodaparast (2015) \\
\hline Paecilomyces variotii & Senthilkumaret al. (2014), Demir et al. (2007) and Kamali and Khodaparast (2015) \\
\hline Phlebia radiata & Aftab et al. (2011), Senthilkumaret al. (2014) and Demir et al. (2007) \\
\hline Bjerkandera spp. & Aftab et al. (2011), Senthilkumaret al. (2014) and Demir et al. (2007) \\
\hline $\begin{array}{l}\text { Phanerochaete chrysosporium } \\
\text { and T. hirsute }\end{array}$ & Sarithaet al. (2010), Senthilkumaret al. (2014) and Demir et al. (2007) \\
\hline \multicolumn{2}{|l|}{ Bacteria } \\
\hline Pseudomonas ovalis & Tyagi et al. (2014), Raj et al. (2007) and Kamali and Khodaparast (2015) \\
\hline Pseudomonas aeruginosa & $\begin{array}{l}\text { Raj et al. (2007), Hao et al. (2000), Chandra et al. (2011), Chandra and Bharagava (2013), } \\
\text { Keharia and Madamwar (2003), Tikuet al. (2010) and Kamali and Khodaparast (2015) }\end{array}$ \\
\hline Bacillus cereus & $\begin{array}{l}\text { Raj et al. (2007), Hao et al. (2000), Chandra et al. (2011), Chandra and Bharagava (2013), } \\
\text { Tiku et al. (2010) and Kamali and Khodaparast (2015) }\end{array}$ \\
\hline \multicolumn{2}{|l|}{ Algae } \\
\hline Microcystis spp. & Iyovoet al. (2010) and Sharma et al. (2014) \\
\hline $\begin{array}{l}\text { Chlorella, Chlamydomonas } \\
\text { Enzymes }\end{array}$ & Iyovoet al. (2010), Sharma et al. (2014) and Kamali and Khodaparast (2015) \\
\hline Ligninase & $\begin{array}{l}\text { Raj et al. (2014), Gao et al. (2010, 2013), Chakar and Ragauskas (2004) and Dashtbanet al. } \\
\text { (2010) }\end{array}$ \\
\hline Cellulase & $\begin{array}{l}\text { Raj et al. (2014), Gao et al. (2010, 2013), Chakar and Ragauskas (2004) and Dashtbanet al. } \\
\text { (2010) }\end{array}$ \\
\hline Peroxidase & $\begin{array}{l}\text { Raj et al. (2014), Gao et al. (2010, 2013), Chakar and Ragauskas (2004) and Dashtbanet al. } \\
\text { (2010) }\end{array}$ \\
\hline
\end{tabular}

tion of dissolved oxygen (Ragunathan and Swaminathan, 2004).

The generation of waste water and characteristics of PPME depends totally on manufacturing process adopted and the extent of reuse of water employed in the plant. The effluent of kraft pulping is highly polluted and characterized by parameters such as colour, absorbable organic halides (AOX) and related organic compounds. The alkaline extraction stage of bleach plant effluent is the major source of colour due to lignin and its derivatives (Bajpai et al., 1993). Lignin wastewater is discharged from the pulping, bleaching and chemical recovery sections. Lignin is a heterogeneous, three dimensional polymer, composed of oxyphenylpropanoid units. The high chlorine content of bleached plant reacts with lignin and its derivatives converted into highly toxic and recalcitrant compounds and the responsible for high BOD and COD. Trichlorophenol, trichloroguicol, tetrachloroguicol, dichlorophenol, dichoroguicol and pentachlorophenol are major contaminants formed in PPME (Leuenberger et al., 1985).

Effects of pulp and paper mill effluent: The most noticeable effects on receiving water were reduced oxygen levels, eutrophication and deposition of sludges and associated microbial growth. Many chlorinated organic compounds have been detected in PPME, in receiving water and in biota exposed to pulp and paper mill discharges (Dey et al., 2013). These chlorinated compounds are highly toxic included phenolics, fatty acids and resin acids as well as dioxins and furans (Ali and Sreekrishnan, 2001). Pulp and paper industry is one of the most polluting industries contributing 100 million $\mathrm{kg}$ of toxic pollutants every year in the environment (Dey et al., 2013). More than 260 chemicals have been identified in PPME which are produced at different stages of papermaking (Hawkins et al., 2002). The toxic nature is due to several naturally occurring and xenobiotic compounds which are formed and released during various stages of processing (Sharma et al., 2007). The PPME absorb more light and heat and retain less oxygen due to a large amount of tannins, thereby negatively affecting the aquatic flora and fauna. The condensed tannins from spruce bark are toxic to methanogens present in PPME and also to aquatic organisms like fish by changing their behavioral response, development and growth, impact on the immune system, impact on enzymes and reproductive 
(Dey et al., 2013; Mishra et al., 2011).

Various studies have reported damaging effects of PPME on animals living in water bodies receiving the effluent. The effects are in the form of respiratory stress, oxidative stress, liver damage and geno-toxicity (Vass et al., 1996). Health impacts such as diarrhea, vomiting, headaches, nausea and eye irritation in children and workers were reported due to the PPME discharge to the environment (Mandal and Bandana, 1996). The effluent has a high chemical diversity of organic chemicals present in it. Many of them are carcinogenic, mutagenic, clastogenic and endocrinic disrupters. A study on Bacillus Subtilis reported the mutagenic effects by the effluent of kraft paper mill (Kinae et al., 1981).

Another study reports the toxic and mutagenic effects of PPME contaminating lake Baikal (Lindstrom-Seppa et al., 1998). Exposure to the PPME adversely affects diversity and abundance of phytoplankton, zooplankton and zoobenthos, disrupting benthic algal and invertebrate communities (Karrasch et al., 2006). Therefore it is mandatory to treat the effluent before disposal.

Bidegradation of pollutants in PPME: Since last many years, the pollutants removal from PPME is the major problem and a subject of study. The colour is the main problem in PPME which is mainly due to lignin and lignin derivatives. A Large amount of lignin produced from various processes such as pulping, bleaching and recovery sections.

Various methods have been used for the removal of colour from PPME. Physical and chemical methods are relatively expensive and eliminate some chlorinated lignins, colour, toxicity, suspended solids and COD but BOD and some other chemicals can not be removed efficiently. The biological method is a comparatively better option to reduce colour and COD; it also reduces $\mathrm{BOD}$ and other chemicals.

Bioremediation is a technology that utilizes biological systems to catalyze the degradation or transformation of various toxic chemicals to less harmful forms. So, bioremediation is employed for the treatment of various industrial effluents like PPME (Wu et al., 2005; Yang et al., 2008).

Biological treatment: Biological treatment methods involve the utilization of microorganisms like fungi, bacteria, algae and enzymes, as a single step treatment or in combination with other physical and/or chemical methods (Singhal and Thakur, 2009). Biological methods for wastewater treatment are comparatively cost effective, eco-friendly and appropriate for reduction BOD as well as COD from the effluents.

Treatment with fungi: The fungi are naturally present in PPME as well as sludge (Yang et al., 2011) and they produce extracellular enzymes (Kamali and Khodaparast, 2015). Schizophyllum commune, Tinctoria borbonica, Phanerochaete chrysosporium and Trametes versicolor have been found to be helpful for degradation and metabolism of lignin along with carbohydrates. Aspergillus niger and Trichoderma sp. are also capable of degrading lignin and decolorizing effluent of hardwood pulp bleaching (Dashtban et al., 2010). The nutrients can improve the decolourizing efficiency of the fungus and also reduce BOD and COD of the effluent. Sucrose was found to be the best co-substrate for the degradation of lignin (Tiku et al., 2010; Kamali and Khodaparast, 2015). The use of Tinctoria borbonica has removed $90-99 \%$ color in 4 days of incubation (Abd El-Rahim and Zaki, 2005). Schizophyllum commune can be removed the $90 \%$ colorof effluent and also reduced BOD and COD by $70 \%$ and $72 \%$ respectively under optimum conditions in 2 days incubation (Saritha et al., 2010).

Gliocladiumvirens has been employed for the treatment of PPME, and it was observed that the fungus grew efficiently in the presence of effluent and decolourized upto $42 \%$ and also decreased lignin (52\%), cellulose $(75 \%)$ and BOD (65\%) in effluents (Kamali and Khodaparast, 2015).

Phanerochaete chrysosporium can degrade the lignin and remove the color of PPME, therefore which has been studied in much detail by Senthilkumar et al. (2014), Demir et al. (2007) and Gomaa et al. (2008). Coriolus versicolor secretes an extracellular enzyme laccase, which helps in lignin degradation (Aftab et al., 2011). Coriolus versicolor in liquid culture reduced $60 \%$ color of the effluent in 6 days incubation in the presence of sucrose. Fungus Coriolus versicolor immobilized in calcium alginate beads have been used in airlift bioreactor for the treatment of PPME (Verma and Madamwar, 2002).

The Cyrus stercoreus can also degrade lignin as efficiently as like as other white rot fungi did (Achoka, 2002; Saritha et al., 2010). The Trametes versicolor strain B7 oxidized the chromophores present in PPME in the presence of the carbohydrates, and highest decolourization was reported in the presence of glucose at optimum condition, $\mathrm{pH} 4.5-5.5$ and temperature $30^{\circ} \mathrm{C}$ (Diez et al., 1999).

Decolourization of PPME was reported maximum decolourization of $34 \%$ by Trametes versicolor on third day incubation in effluent supplemented with $1.0 \%$ $(\mathrm{w} / \mathrm{v})$ glucose as co-substrate and $0.2 \%(\mathrm{w} / \mathrm{v})$ urea as nitrogen source (Singhal and Thakur, 2009).

Sordariafimicola, Halosatpheia sp. and Basidiomycetes sp. can produce the lignin modifying enzymes; laccase, manganese peroxidase (MNP) and ligninperoxidase (LP) (Kamali and Khodaparast, 2015).

Sumathi and Phatak (1999) investigated the capability of Aspergillus foelidus to colour removal, COD reduction and lignin metabolism. The cellulose degradation by Pleurotus sajor-caju was rapid at the initial stages of growth. The activity of endoglucanase, exoglucanase and beta-glucosidase were maximum at 8, 12 and 26 days of incubation, respectively (Atkins and 
Clark, 2004; Ramos et al., 2009).

The optimum conditions for fungal growth are quite different from degradation. The $\mathrm{pH}$ range for optimum growth was 4.3 to 4.8 and degradation is retarded below $\mathrm{pH} 4.0$ and above $\mathrm{pH} 5.0$ due to lowering growth. Therefore, suggesting that the $\mathrm{pH}$ does not play a critical role in the treatment of PPME (Sarithaet al., 2010). The optimum temperature for the growth of fungus was $40^{\circ} \mathrm{C}$ where as the treatment is not much affected to the same narrow range of the temperature but slightly decrease in the rate at a temperature as low as $25^{\circ} \mathrm{C}$ (Tiku et al., 2010). The fungal degradation needs oxygen and a co substrate but not requires the addition of nitrogen source (Verma and Madamwar, 2002).

Treatment with bacteria: Various bacterial species have been evaluated for their decolorization abilities. Bacillus subtilis and Micrococcus luteus were found competent of reducing BOD up to $87.2 \%$, COD up to $94.7 \%$ and lignin content up to $97 \%$ after 9 days under shaking conditions and brought down $\mathrm{pH}$ of PPME to neutral (Tyagi et al., 2014).

Pseudomonas aeruginosa is capable of reducing PPME color by $26-54 \%$ or more under aerobic conditions (Ramsay and Nguyen, 2002). Tiku et al. (2010) and Raj et al. (2007) were tested Bacillus cereus and two strains of Pseudomonas aeruginosa for the decolorization of PPME.

Streptomycetes badius and S. viridosporous were able to use a commercial kraft lignin as sole carbon source which was characterized by fourier transformed infrared spectroscopy, amino acid analysis, elemental analysis for $\mathrm{C}, \mathrm{H}, \mathrm{N}$ and high performance size exclusion chromatography (Abd El-Rahim and Zaki, 2005; Chandra et al., 2011).

Pseudomonas putida and Acienetobacter calcoaceticus were studied for degradation of black liquor from a kraft pulp and paper mill in a continuous reactor. They were able to remove $70-80 \%$ of COD and lignin while, the colour removal efficiency was around $80 \%$ in 8 days (Murugesan, 2003).

Burkholderia cepacia strains hydrolysed tri-glycerides to free fatty acids. Nearby $30 \%$ of the stearyl esters, $25 \%$ of the dehydro abietic and $45 \%$ of the abietic and iso-pimaric resin acids were degraded during 11 days (Aftab et al., 2011).

Apart from the investigation, mixed consortia of aerobic and anaerobic microbes for resin acid degradation, researchers have employed pure cultures of several bacteria which include Bacillus sp., E. coli, Flavobacterium sp., Pseudomonas, Acaligenes eutrophus, Anthrobacter, Sphinomonas, Zooglea, Commamonas, Mortierella isabella, Chaetomium cochliolidae, Corticum sasaki and Fomesannosus (Tiku et al., 2010; Raj et al., 2014). Wilson et al. (1996) isolated two species of Pseudomonas, IpA-1 and IpA-2 which were capable of growing on isopimaric acid as the sole carbon source and an electron donor. These isolates were also found to grow on pimaric acid and dehydroabietic acid.

Bacillus SAM3 producing high levels of cellulose free xylanase active and stable at alkaline $\mathrm{pH}$ (Chandra and Singh, 2012). Actinomycetes, isolated from different soil samples were tested for their ability to utilize sulphite in PPME. The AOX values of the higher molecular weight fractions were also reduced. Extracellular peroxidase and cell wall-bound catalase activities were produced during growth of the microorganisms on bleach effluents (Chandra et al., 2012).

Pseudomonas putida, Citrobaterer sp. and Enterobacter sp. can decolorized effluent up to $97 \%$ and also can reduce BOD, COD, phenolics and sulphide upto $96.63 \%, 96.80 \%, 96.92 \%$ and $96.67 \%$ respectively within $24 \mathrm{~h}$ of growth and the heavy metals were removed upto $82-99.80 \%$ (Keharia and Madamwar, 2003).

It was observed that as the $\mathrm{pH}$ of PPME was dropped to as low as 2.0 because of the settling properties of the effluent are increased tremendously. This could be due to the precipitation of negatively charged lignin components and the bacterial cells due to increased protonation of the medium. The color intensity increased, as the $\mathrm{pH}$ was made alkaline up to 10 . Thus, suggesting that $\mathrm{pH}$ plays an acrucial role in the color of PPME. Additional carbon source plays an important role in degradation process. A number of studies revealed that the color removal ability increased by about $20-25 \%$ by the addition of nutrients like glucose and sucrose. There is a negative impact in practical applicability due to excessive growth of biomass, leading to high turbidity in the samples. So, the use of additional nutrient sources of carbon was summarily rejected by the workers, considering the practical applicability of the technology. In decolourization studies, generally, a range of 50-200 rpm was selected. It was observed that percentage of removal of color was highest at about $150 \mathrm{rpm}$, after which it became stable. Different effluent biomass ratios (1:1, 1:0.5, 1:0.25 and 1:2) were tried, and finally, the results suggested that $P$. aeruginosa (DSMZ 03504) and consortium produced the best results when used in the $1: 1$ ratio (Tiku et al., 2010). Adsorption is playing a major role to contribute the removal of color. $P$. aeruginosa was taken out from the wastewater, after the decolorization experiment and analyzed by scanning electron microscopy. Scanning electron microscopy studies showed that the bacterial cells adhering to the colored material present in the wastewater exhibited some extra cellular secretion visible on the cell surfaces which was absent in the control cells. The surfaces of the cells growing in the wastewater were not as smooth as seen in the control cells. This would mean that adsorption could be a major contributor to color removal. However, the extent of adsorption was not clear and further study is required (Tiku et al., 2010). 
Treatment with algae: It has been reported that some algae like Microcystis sp. can decolourize diluted bleach kraft mill effluents (Iyovo et al., 2010; Sharma et al., 2014). According to Chandra and Singh (2012), pure and mixed algal cultures removed up to $70 \%$ of colour within two months of incubation. Mostly cultures showed a similar colour reduction pattern consisting of a phase with declining rate. The decolorization was maximum remedial during the first 15-20 days of incubation and then gradually declined. The decolorization by algae is caused by metabolic transformation ofcoloured molecules to colourless molecules. Mixed culture of Chlorella, Chlamydomonas and Microcystis were used for removal AOX and colour, and it was reported $70 \%$ AOX reduction while $80 \%$ color reduction in 30 days. Many authors concluded through analysis of alkaline extraction of algal biomass that the main color removal mechanism was metabolism rather than adsorption (Sharma et al., 2014; Chandra and Singh, 2012).

Treatment with biological enzymes: Few enzymes like ligninase, cellulase and peroxidase are showing potential to remove organic matter from PPME and also improve the quality of wastewater. Out of them the most important enzymes, especially peroxidase which is used for colour removal in bleaching effluents. It is also possible to mix enzymes together with special microbes which normally do not have high enzyme activity for decolourization process. Some fungus produces peroxidase, extracellular enzymes. It seems that this enzyme oxidizes the chromophores and removes the colour from bleaching wastewater. The colour removal from effluents at neutral $\mathrm{pH}$ by low levels of hydrogen peroxide $\left(\mathrm{H}_{2} \mathrm{O}_{2}\right)$ was enhanced by the addition of peroxidase (Raj et al., 2014;Gao et al., 2013).

\section{Conclusion}

The comparison of treatment by different methods showed that native microbes isolated from the site of pulp and paper mill have the ability to use lignin, as a carbon source and reduce the COD, BOD and other contaminants. With the increased demand for paper, the treatment of effluents emerges as a most pressing problem in environmental protection. Presently, bioremediation is taken to be an attractive option for reducing the pollution load from contaminated water because of its high efficiency and economical impact than the chemical remediation. The current study clearly showed that application of native dominant bacterial and fungal isolates could be used for the treatment of large pulp and paper mills effluents. The comparison of decolourisation by different organisms showed that some fungus (Aspergillus niger, Phanerochaete chrysosporium and Trametes versicolor) and some bacteria (Pseudomonas ovalis, Pseudomonas aeruginosa and Bacillus cereus) are suitable for efflu- ent degradation of recalcitrant chromophoric material in paper mill effluent. The fungal and bacterial isolates having appropriate enzyme activity with optimized proper physical conditions are playing a significant role in the bioremediation process. Further research is needed to develop fast biodegradation processes which are likely to provide an economically feasible process.

\section{REFERENCES}

Abd El-Rahim, W.M. and Zaki, E.A. (2005). Functional and molecular characterization of native Egyptian fungi capable of removing textile dyes. Arab J. Biotech., 8: 189-200.

Achoka, J. D. (2002). The efficiency of oxidation ponds at the kraft pulp and paper mill at Webuye in Kenya. $\mathrm{Wa}$ ter Res., 36: 1203-1212.

Aftab, U., Khan, M.R.,Mahfooz,M. Ali,M., Aslam S.H.and Rehman, A. (2011). Decolourization and degradation of textile Azo dyes by Corynebacterium sp. Isolated from industrial effluent. Pak. J. Zool., 43: 1-8.

Alexander M. (1981). Biodegradation of chemicals of environment concern. Science 211:132-138.

Ali, M. and Sreekrishnan, T.R. (2001). Aquatic toxicity from pulp and paper mill effluents: A review. Adv. Environ. Res., 5: 175-196.

Atkins, S.D. and Clark, I.M. (2004). Fungal molecular diagnostics: A mini review. J. Applied Genet., 45: 3-15.

Atlas, R. M. and Bartha R. (2003). In microbial ecology: Fundamentals and applications. 4th edition. Benjamin and cummings science publishing, Callifornia

Badar S. and Farooki I. H. (2012). Pulp and paper industryManufacturing process, wastewater generation and treatment. In: Malik A., Grohmann E. (eds) Environmental protection strategies for sustainable development. Strategies for sustainability. Springer, Dordrecht

Bajpai, P., Mehna, A., Bajpai, P. K. (1993). Decolorization of kraft bleach plant effluent with the white rot fungus Trametes versicolor. Process Biochem., 28: 377-384.

Chakar, F.S. and Ragauskas, A.J. (2004). Review of current and future softwood Kraft lignin processchemistry. Ind. Crops Prod., 20: 131-141.

Chandra, R. and Bharagava, R.N. (2013). Bacterial degradation of synthetic and kraft lignin byaxenic and mixed culture and their metabolic products. J. Environ. Biol., 34: 991-999.

Chandra, R. and Singh, R. (2012). Decolourisation and detoxification of rayon grade pulp paper mill effluent by mixed bacterial culture isolated from pulp paper mill effluent polluted site. Biochem. Eng. J., 61: 49-58.

Chandra, R., Abhishek, A. and Sankhwar, M. (2011). Bacterial decolorization and detoxification of black liquor from rayon grade pulp manufacturing paper industry and detection of their metabolic products. Bioresour. Technol., 102: 6429-6436.

Chandra, R., Raj, A., Purohit, H.J. and Kapley, A. (2007). Characterisation and optimisation of three potential aerobic bacterial strains for kraft lignin degradation from pulp paper waste. Chemosphere, 67: 839-846.

Chandra, R., Singh, R. and Yadav, S. (2012). Effect of bacterial inoculum ratio in mixed culture for decolourization and detoxification of pulp paper mill effluent. J. Chem. Technol. Biotechnol., 87: 436-444. 
Dashtban, M., Schraft, H., Syed, T.A. and Qin,W. (2010). Fungal biodegradation and enzymatic modification of lignin. Int. J. Biochem. Mol. Biol., 1: 36-50.

Demir, G., Ozcan, H.K., Tufekci, N. and Borat, M. (2007). Decolorization of remazol yellow RR Gran by white rot fungus Phanerochaete chrysosporium. J. Environ. Biol., 28: 813-817.

Dey, S., Choudhury, M.D. and Das, S. (2013). A review on toxicity of paper mill effluent on fish. Bull. Environ. Pharmacol. Life Sci., 2: 17-23.

Diez, M.C., Mora, M.L. and Videla, S. (1999). Adsorption of phenolic compounds and color from bleached Kraft mill effluent using allophanic compounds. Water Res., 33: 125-130.

D'Souza, D.T., Tiwari, R., Sah, A.K. and Raghukumar, C. (2006). Enhanced production of laccase by a marine fungus during treatment of colored effluents and synthetic dyes. Enzyme Microb. Technol., 38: 504-511.

Gao, J., Xu,G., Qian, H., Liu, P., Zhao, P. and Hu, Y. (2013). Effects of nano-TiO2 on photosynthetic characteristics of Ulmus elongate seedlings. Environ. Pollut., 176: 6370

Gao, W.J.J., Lin, H.J,. Leung, K.T. and Liao, B.Q. (2010). Influence of elevated $\mathrm{pH}$ shocks on theperformance of a submerged anaerobic membrane bioreactor. Process Biochem., 45: 1279-1287.

Gomaa, O.M., Linz, J.E. and Reddy, C.A. (2008). Decolorization of Victoria blue by the white rot fungus, Phanerochaete chrysosporium. World J. Microbiol. Biotechnol., 24: 2349-2356.

Hanafy, A.A., Elsalam, H.E. and Hafez, E.E. (2007). Fingerprinting for the lignin degrading bacteria from the soil. J. Applied Sci. Res., 3: 470-475.

Hao, O.J., Kim, H. and Chiang, P.C. (2000). Decolorization of wastewater. Crit. Rev. Environ. Sci.Technol., 30: 449 -505 .

Hawkins, S.A., Billiard, S.M., Tabash, S.P., Brown, R.S. and Hodson, P.V. (2002). Altering cytochrome p4501a activity affects polycyclic aromatic hydrocarbon metabolism and toxicity in rainbow trout (Oncorhynchus mykiss). Environ. Toxicol. Chem., 21: 1845-1853.

Hossain, K. and Rao, A.R. (2014). Environmental change and it's affect. Eur. J. Sustain. Dev., 3: 89-96.

Iyovo, G.D., Du, G. and Chen, J. (2010). Sustainable bioenergy bioprocessing: Biomethane production, digestate as biofertilizer and as supplemental feed in algae cultivation to promote algae biofuel commercialization. $J$. Microb. Biochem. Technol., 2: 100-106.

Kamali, M. and Khodaparast, Z. (2015). Review on recent developments on pulp and paper mill wastewater treatment. Ecotoxicol. Environ. Saf., 114: 326-342.

Karrasch, B., Parra, O., Cid, H., Mehrens, M., Pacheo, P., Urrutia, R., Valdovinos, C. andZaror C. (2006). Effects of pulp and paper Mill effluents on the microplankton and microbial self-purification capabilities of the Biobio river. Chile. Sci Total Environ 359:194-208.

Keharia, H. and Madamwar, D. (2003). Bioremediation concepts for treatment of dye containing wastewater: A review. Indian J. Exp. Biol., 41: 1068-1075.

Kinae, N., Hashu, T., Makita, T., Tomita, I., Kimura, I. and Kanamori, H. (1981). Studies on the toxicity of pulp and paper mill effluents : mutagenicity of the sediment samples derived from kraft paper mills. Water Res., $15: 17-24$.

Kucerova, R. (2006). Application of Pseudomonas putida and Rhodococcus sp. by biodegradation of $\mathrm{PAH}(\mathrm{S})$, $\mathrm{PCB}(\mathrm{S})$ and NEL soil samples from the hazardous waste dump in pozdatky (Czech republic). Rud.-geol.naft. Zb.,1897:101.

Leuenberger, C., Geger, W., Coney, R., Grayder, J. M., Molnar-Kubica, E. (1985). Persistence chemicals in pulp mill effluent: occurrence and behavior in an activated sludge treatment plant. Water Res., 19:885-894.

Lindstrom-Seppa, P., Hunskonen, S., Kotelevtsev, S., Mikkelson, P. and Rannen, T. (1998). Toxicity and mutagenicity of waste waters from Baikalsk pulp and paper mill:Evaluation of pollutant contamination in Lake Baikal. Mar. Environ. Res., 46:273-277.

Malaviya, P. and Rathore, V. S. (2007). Bioremediation of pulp and paper mill effluent by a novel fungal consortium isolated from polluted soil. Biores. Technol.,98:3647-3651.

Mandal, T. N. and Bandana, T. N. (1996). Studies on physicochemical and biological characteristics of pulp and paper mill effluents and its impact on human beings. $J$. Fresh Biol., 8:191-196.

Mishra, A., Tripathi, C.P.M., Dwivedi, A.K. and Dubey, V.K. (2011). Acute toxicity and behavioral response of freshwater fish, Mystusvittatus exposed to pulp mill effluent. J. Environ. Chem. Ecotoxicol., 3: 167-172.

Monte, M.C., Fuente, E., Blanco, A. and Negro, C. (2009). Waste management from pulp and paper production in the European Union. Waste Manage., 29: 293-308.

Mueller, J.G., Cerniglia, C.E. and Pritchard, P.H. (1996). Bioremediation of environments contaminated by polycyclic aromatic hydrocarbons. In Bioremediation: Principles and applications. Cambridge University Press, Cambridge. 125-194.

Murugesan, K. (2003). Bioremediation of paper and pulp mill effluents. Ind. J. Exp. Biol., 441: 1239-1248.

Nagarthnamma, R., Bajpai, P. and Bajpai, P.K. (1999). Studies on decolourization, degradation and detoxification of chlorinated lignin compounds in kraft bleaching effluents by Ceriporiopsis subvermispora. Process Biochem., 34: 939-948.

Patel, H. and Madamwar, D. (2002). Effects of temperatures and organic loading rates on biomethanation of acidic petrochemical wastewater using an anaerobic upflow fixed-film reactor. Bioresour. Technol., 82(1):65-71.

Prasongsuk, S., Lotrakul, P., Imai, T. and Punnapayak, H. (2009). Decolourization of pulp mill wastewater using thermotolerant white rot fungi. Sci. Asia, 35: 37-41.

Ragunathan, R. and Swaminathan, K. (2004). Biological treatment of pulp and paper industry effluent by Pleurotus spp. World J. Micro. Biotech., 20:389-393.

Raj, A., Kumar, S., Haq, I. and Singh, S.K. (2014). Bioremediation and toxicity reduction in pulp and paper mill effluent by newly isolated ligninolytic Paenibacillus sp. Ecol. Eng., 71: 355-362.

Raj, A., Reddy, M.M.K,. Chandra, R., Purohit, H.J. and Kapley, A. (2007). Biodegradation of kraft-lignin by Bacillus sp. Isolated from sludge of pulp and paper mill. Biodegradation, 18: 783-792.

Ramos, W.D.L.S., Poznyak, T., Chairez, I. and Cordova, R.I. (2009). Remediation of lignin and its derivatives from 
pulp and paper industry wastewater by the combination of chemical precipitation and ozonation. J. Hazard. Mater., 169: 428-434.

Ramsay J.A. and Nguyen, T. (2002). Decoloration of textile dyes by Trametes versicolor and its effect on dye toxicity. Biotechnology Lett., 24(21):1757-1761.

Saritha, V., Maruthi, Y.A. and Mukkanti, K. (2010). Potential fungi for bioremediation of industrial effluents. Bio. Resources, 5: 8-22.

Senthilkumar, S., Perumalsamy, M. and Prabhu, H.J. (2014). Decolourization potential of white-rot fungus Phanerochaete chrysosporiumon synthetic dye bath effluent containing Amido black 10B. J. Saudi Chem. Soc., 18: 845-853.

Sharma, P., Goel, R. and Capalash, N. (2007). Bacterial laccases. World J. Microbiol. Biotechnol., 23: 823-832.

Sharma, R., Chandra, S., Singh, A. and Singh, K. (2014). Degradation of pulp and paper mill effluents. IIOAB J., 5: 6-12.

Singhal, A. and Thakur, I.S. (2009). Decolourization and detoxification of pulp and paper mill effluent by Cryptococcus sp. Biochem. Eng. J., 46: 21-27.

Sumathi, S. and Phatak, V. (1999). Fungal treatment of bagasse based pulp and paper mill wastes. Environ. Technol., 20: 93-98.

Tiku, D.K., Kumar, A., Chaturvedi, R.,Makhijani, S.D.,Manoharan, A. and Kumar, R. (2010). Holistic bioremediation of pulp mill effluents using autochthonous bacteria. Int. Biodeterior. Biodegrad., 64:173-183
Tyagi, S., Kumar, V., Singh, J., Teotia, P., Bisht, S. and Sharma, S. (2014). Bioremediation of pulp and paper mill effluent by dominant aboriginal microbes and their consortium. Int. J. Environ. Res., 8: 561-568.

US EPA., (1995). EPA office of compliance sector notebook project: profile of pulp and paper industry, Washington, DC 20460. US EPA/310-R-95-015.

Vass, K. K., Mukopadhyay, M. K., Mistra, K. and Joshi, H. C. (1996). Respiratory stresses in fishes exposed to paper and pulp wastewater. Environ. Ecol., 14:895-897

Verma, P. and Madamwar, D. (2002). Production of ligninolytic enzymes for dye decolorization by cocultivation of white-rot fungi Pleurotus ostreatus and Phanerochaete chrysosporium under solid-state fermentation. Appl. Biochem. Biotechnol., 102: 109-118.

Wilson, A.E., Moore, E.R. and Mohn, W.W. (1996). Isolation and characterization of isopimaric acid-degrading bacteria from a sequencing batch reactor. Appl. Environ. Microbiol., 62: 3146-3151.

Wu, J., Xiao, Y.Z. and Yu, H.Q. (2005). Degradation of lignin in pulp mill wastewaters by white-rot fungi on biofilm. Bioresour. Technol., 96: 1357-1363.

Yang, C., Cao, G., Li, Y., Zhang, X. and Ren, H. (2008). A constructed alkaline consortium and its dynamics in treating alkaline black liquor with very high pollution load. PLoS One, 3 (10): 1371

Yang, Q., Angly, F.E., Wang, Z. and Zhang, H. (2011). Wastewater treatment systems harbor specific and diverse yeast communities. Biochem. Eng. J., 58(59):168-176 